УДК 616.314-018.4-085.27-02:612.015.11]-092

DOI 10.11603/2311-9624.2018.2.8812

CВ. М. Зубачик, I. В. Ган, О. О. Пасько

Львівський національний медичний університет імені Данила Галицького

\title{
Оцінка впливу остеотропних препаратів на активність процесів пероксидного окиснення ліпідів та антиоксидантної системи при регенерації кісткової тканини в експерименті
}

Резюме. У статті наведено порівняльну оцінку динаміки репараційного процесу в кістковій тканині під впливом остеотропних препаратів.

Мета дослідження - оцінити вплив препаратів та композицій для ендодонтичного лікування на інтенсивність репараційного процесу в кістковій тканині, аналізуючи результати біохімічних досліджень пероксидного окиснення ліпідів та антиоксидантної системи.

Матеріали і методи. Експеримент проведено на 120 білих щурах, яким створювали дефект кісткової тканини та заповнювали його досліджуваними біоматеріалами. 3 досліду тварин виводили на 14 та 30 доби шляхом декапітації під наркозом та проводили забір крові для біохімічних досліджень. У крові щурів досліджували активність процесів пероксидного окиснення ліпідів - малонового діальдигіду та ферментів антиоксидантної системи - каталази та супероксиддисмутази.

Результати досліджень та їх обговорення. У групах тварин, де використовували композиції на основі гідроксіапатиту і $\beta$-трикальційфосфату, спостерігалась менша активність процесів ліпопероксидації порівняно з тваринами, де застосовували MTA та Nano Gen. Запропоновані композиції володіють антиоксидантними властивостями, що сприяють зменшенню активності запального процесу. Композиції на основі гідроксіапатиту і $\beta$-трикальційфосфату в більш ранні терміни відновлюють баланс в системі пероксидного окиснення ліпідів та антиоксидантної системи, що створює сприятливіші умови для біоревіталізації та регенерації позаапікальних тканин.

Висновки. Композиції на основі гідроксіапатиту і $\beta$-трикальційфосфату володіють антиоксидантними властивостями, пригнічують процеси надмірної ліпопероксидації, сприяють зменшенню активності запального процесу і, тим самим, стимулюють регенерацію кісткової тканини.

ключові слова: біоматеріали; регенерація; експеримент; малоновий діальдегід; каталаза; супероксиддисмутаза.

\section{CВ. М. Зубачик, И. В. Ган, О. А. Пасько}

Львовский национальный медицинский университет имени Данила Галицкого

\section{Оценка влияния остеотропных препаратов на активность процессов пероксидного окисления липидов и антиоксидантной системы при регенерации костной ткани в эксперименте}

Резюме. У статье приведена сравнительная оценка динамики репарационного процесса в костной ткани под влиянием препаратов и предложенных композиций для эндодонтического лечения.

Цель исследования - оценить влияние препаратов и композиций для эндодонтического лечения на интенсивность репарационного процесса в костной ткани, анализируя результаты биохимических исследований пероксидного окисления липидов и антиоксидантной системы.

Материалы и методы. Эксперимент проведен на 120 белых крысах, которым создавали дефект костной ткани и заполняли его исследуемыми биоматериалами. С опыта животных выводили на 14 и 30 сутки путем декапитации под наркозом и проводили забор крови для биохимических исследований. В крови крыс исследовали активность процессов пероксидного окисления липидов - малонового диальдигида и ферментов антиоксидантной системы - каталазы и супероксиддисмутазы.

Результаты исследований и их обсуждения. В группах животных, где использовали композиции на основе гидроксиапатита и $\beta$-трикальцийфосфата наблюдалась меньшая активность процессов липопероксидации по сравнению с животными, где применяли MTA и Nano Gen. Предложенные композиции обладают антиоксидантными свойствами, которые способствуют уменьшению активности воспалительного процесса. Композиции на основе гидроксиапатита и $\beta$-трикальцийфосфата в более ранние сроки восстанавливают баланс в системе пероксидного окисления липидов и антиоксидант- 
ной системы, создает благоприятные условия для биоревитализации и регенерации позаапикальних тканей.

Выводы. Композиции на основе гидроксиапатита и $\beta$-трикальцийфосфата обладают антиоксидантными свойствами, подавляют процессы чрезмерной липопероксидации, способствуют уменьшению активности воспалительного процесса, стимулирует регенерацию костной ткани.

Ключевые слова: биоматериалы; регенерация; эксперимент; малоновый диальдегид; каталаза; супероксиддисмутаза.

COV. M. Zubachyk, I. V. Han, O. O. Pasko

Danylo Halytskyi Lviv National Medical University

\section{Evaluation of influence of osteotropic drugs on activity of lipid peroxidation and antioxidant system processes for bone tissue regeneration in the experiment}

Summary. The comparative estimation of the dynamics of the reparative process in bone tissue under the influence of MTA and Nano Gen preparations and the proposed compositions based on hydroxyapatite and $\beta$-tricalcium phosphate for endodontic treatment is given.

The aim of the study - to determine the dynamics of reparative processes in bone tissue under the influence of drugs and compositions for endodontic treatment, which is based on the analysis of the results of biochemical studies of lipid peroxidation and antioxidant system.

Materials and Methods. The experiment was conducted on 120 white rats, on which the defect of bone tissue was created and filled with the studied biomaterials. From the experiment the animals were excised at 14 and 30 days by decapitation under anesthesia and blood samples were taken for biochemical studies. In the blood of rats, the activity of peroxide oxidation processes of lipids - malonic dialdehyde and antioxidant system enzymes - catalase and superoxide dismutase were studied.

Results and Discussion. In animal groups where hydroxyapatite and $\beta$-tricalcium phosphate based compositions were used, less activity was observed in lipoperoxidation than in animals using MTA and Nano Gen. The proposed compositions possess antioxidant properties that contribute to the reduction of the activity of the inflammatory process. Compositions based on hydroxyapatite and $\beta$-tricalcium phosphate at earlier times restore the balance in the lipid peroxidation system and the antioxidant system, which creates more favorable conditions for biorevitalization and regeneration of non-apical tissues.

Conclusions. The compositions based on hydroxyapatite and $\beta$-tricalcium phosphate possess antioxidant properties, suppress excessive lipoproxidation processes, contribute to the reduction of the activity of the inflammatory process, which stimulates the regeneration of bone tissue.

Key words: biomaterials; regeneration; experiment; malonic dialdehyde; catalase; superoxide dismutase.

Вступ. Однією з актуальних проблем сучасної медицини залишається пошук методик спрямованого впливу на процеси регенерації кісткової тканини [1]. Велика кількість хворих із хронічною формою періодонтиту та значна кількість ускладнень після лікування зумовлюють пошук нових засобів та способів лікування [2, 6-8]. Окрім антисептичної та механічної обробки кореневих каналів і герметичного їх пломбування, надзвичайно важливою ланкою лікування хронічних форм періодонтиту є регенерація кісткової тканини при запально-деструктивних процесах у позаапікальній ділянці зуба, особливо з набутою широкою верхівкою кореня [3, 5]. Низька ефек- тивність ендодонтичного лікування зумовила пошук нових засобів та удосконалення вже існуючих методів лікування, які будуть стимулювати біоревіталізацію та регенерацію позаапікальних тканин [4].

Метою дослідження було оцінити вплив препаратів та композицій для ендодонтичного лікування на інтенсивність репараційного процесу в кістковій тканині, аналізуючи результати біохімічних досліджень пероксидного окиснення ліпідів та антиоксидантної системи.

Матеріали і методи. Експеримент проведено на 120 білих щурах лінії Wistar віком 9-10 тижнів, стадного розведення. Дослідження на 
лабораторних тваринах проводили при дотриманні принципів біоетики відповідно до Європейської конвенції про захист хребетних тварин, що використовуються для дослідних та інших наукових цілей (Страсбург, 1986), положенням Закону України № 3447-IV «Про захист тварин від жорстокого поводження» та були схвалені належним чином місцевим комітетом з питань етики. Для створення дефекту кістки втручання проводили під тіопенталовим наркозом. Щурам з лівого боку нижньої щелепи в ділянці між різцем та правим моляром скальпелем робили трапецеподібний розтин та відсепаровували слизову оболонку. Кулястим та фісурним борами створювали дефект кісткової тканини діаметром 3 мм та глибиною 2,5 мм під постійним зрошенням $0,9 \%$ фізіологічним розчином, який заповнювали досліджуваними біоматеріалами, або залишали із кров'яним згустком та закривали слизовою оболонкою і накладали шви. Усіх тварин було поділено на 6 дослідних груп по 20 особин у кожній: перша група - інтактні тварини, які слугували контролем; друга група - тварини, яким було створено дефект кісткової тканини без уведення біоматеріалу; третя група - тварини, яким для заповнення дефекту використовували матеріал Nano Gen; четверта група - тварини, яким у створений дефект вносили мінерал тріоксид агрегат (MTA); п’ята група - тварини, яким дефект заповнювали композицією на основі $\beta$-трикальційфосфату ( $\beta$-ТКФ); шоста група - тварини, яким у створений дефект кісткової тканини вносили аналогічну композицію на основі гідроксиапатиту кальцію та органічних біоревіталізантів (ГА) (патент на корисну модель № 95974, Україна). Тварин, окрім групи контролю, у перші три дні після початку експерименту утримували на щадній дієті, а в подальшому - в умовах стандартного харчового раціону та згідно з санітарно-гігієнічними нормами у віварії. 3 експерименту щурів виводили на 14 та 30 доби шляхом декапітації під наркозом та проводили забір крові для біохімічних досліджень. У крові щурів досліджували активність процесів пероксидного окиснення ліпідів - малонового діальдигіду (МДА) та ферментів антиоксидантної системи - каталази та супероксиддисмутази (СОД).

Результати досліджень та їх обговорення. Реакції пероксидного окиснення ліпідів у клітинах та функціонуючих системах різко посилюються при дії на організм стресових факторів. Вільні радикали і пероксидні сполуки (МДА), утворені внаслідок цих процесів, здатні спричиняти окиснювальну модифікацію структурних білків та ліпідів клітинних мембран і зумовлювати негативну дію на клітину. За результатами наших досліджень, на 14 добу в другій групі тварин зі створеним дефектом кісткової тканини без введення біоматеріалу встановлено зростання вмісту МДА в 2,3 раза (табл. 1) порівняно з контролем ( $<0,001)$. Аналогічні зміни кількості МДА були в третій та четвертій групах тварин, деструкція кістко-

таблиця 1. Показники концентрації продуктів ПОЛ, ферментів АОС у сироватці крові щурів на 14 добу $(\mathrm{M} \pm \mathrm{m})$

\begin{tabular}{|c|c|c|c|c|}
\hline $\begin{array}{c}\text { Група тварин, } \\
\text { дослідні препарати }\end{array}$ & $\begin{array}{c}\text { МДА } \\
\text { (кмоль/л) }\end{array}$ & $\begin{array}{c}\text { сод } \\
\text { (мккат/л) }\end{array}$ & $\begin{array}{l}\text { Каталаза } \\
\text { (мккат/л) }\end{array}$ & АПI \\
\hline I. Контроль (n=10) & $2,35 \pm 0,03$ & $7,46 \pm 0,27$ & $0,263 \pm 0,012$ & 3,29 \\
\hline $\begin{array}{l}\text { II. Група порівняння } \\
(\mathrm{n}=10)\end{array}$ & 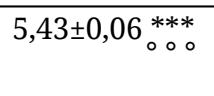 & $4,68 \pm 0,22_{\circ \circ \circ \circ}^{* * *}$ & $0,164 \pm 0,003 \underset{\text { 年。 }}{* * *}$ & 0,89 \\
\hline III. Nano Gen $(n=10)$ & $5,38 \pm 0,05 * * *$ & $4,97 \pm 0,14^{* * *}$ & $0,175 \pm 0,003 \underset{\circ}{* * *}$ & 0,95 \\
\hline IV. MTA $(n=10)$ & $5,35 \pm 0,06 * * *$ & $5,08 \pm 0,16 * * *$ & $0,178 \pm 0,003$ *** & 0,98 \\
\hline $\begin{array}{l}\text { V. Композиція на основі } \\
\beta \text {-ТКФ }(n=10)\end{array}$ & $4,63 \pm 0,04 \underset{\circ * \circ}{* * *}$ & $5,98 \pm 0,21_{\text {○○。 }}^{* * *}$ & $0,212 \pm 0,003 \underset{\substack{* \\
\circ \circ \circ}}{* * *}$ & 1,34 \\
\hline $\begin{array}{l}\text { VI. Композиція на основі } \\
\text { ГА }(n=10)\end{array}$ & $4,48 \pm 0,06 \underset{\substack{* * \circ * \\
\circ \circ \circ}}{* * 0}$ & $6,17 \pm 0,19$ ○。 & $0,217 \pm 0,003 \underset{\circ \circ * \circ}{* * *}$ & 1,43 \\
\hline
\end{tabular}

Примітки: 1) ** - показник вірогідності різниці порівняно з контролем при $\mathrm{p}<0,01 ; 2){ }^{* * *}-\mathrm{p}<0,001$; 3) ${ }^{\circ}-$ показник вірогідності різниці порівняно з групою порівняння при $\mathrm{p}<0,05$;

4) $\left.{ }^{\circ \circ}-\mathrm{p}<0,01 ; 5\right)^{\circ \circ 0}-\mathrm{p}<0,001$. 
вої тканини яких була заповнена біоматеріалами MTA та Nano Gen ( $<<0,001)$. У п’ятій та шостій групах тварин, де використовували композиції на основі $\beta$-ТКФ та ГА, відмічали зростання вмісту МДА - в 2 та 1,9 раза відповідно $(\mathrm{p}<0,001)$.

Одночасно 3 цим були зміни в активності ферментів антиоксидантної системи. Так, у другій групі тварин концентрація СОД та каталази зменшились у 1,6 раза $(\mathrm{p}<0,001)$, а в тварин третьої і четвертої груп активність ферментів знизилась у 1,47 та 1,5 раза відповідно $(\mathrm{p}<0,001)$. Необхідно зазначити, що у п’ятій i шостій дослідних групах відзначали зниження вмісту СОД та каталази лише в 1,25 та 1,21 раза відповідно, порівняно з інтактними тваринами $(\mathrm{p}<0,001)$.

Підвищення концентрації пероксидних радикалів 3 одночасним зниженням активності ферментів антиоксидантної системи свідчить про дисбаланс у системі ПОЛ-АОС унаслідок виснаження антиоксидантних ферментів. Підтвердженням цього $є$ зниження антиоксидантно-прооксидантного індексу (АПІ). Так, у другій групі дослідних тварин АПІ зменшився на $73 \%$, а в третій і четвертій групах - на 71 та 70 \% відповідно (p<0,001). У п’ятій і шостій дослідних групах індекс АПІ знизився лише на 59 та 56 \% відповідно, порівняно з інтактними тваринами $(\mathrm{p}<0,001)$.

ПОЛ вважається одним 3 основних механізмів ушкодження мембранних структур клітини. Унаслідок нагромадження ліпідних пероксидів формуються міжмолекулярні зшивки в ліпопротеїнових структурах, що $\epsilon$ основною причиною змін мікрооточення мембраннозв’язувальних ферментів, рецепторів, іонних каналів. Отже, переважання процесів ліпопероксидації і відносна недостатність ферментів антиоксидантної системи спричиняють ушкодження мембран клітин 3 подальшим порушенням їх функцій.

Через 30 діб після моделювання експериментальної деструкції у другій групі тварин було збільшення концентрації МДА в 1,9 раза, порівняно 3 контролем $(\mathrm{p}<0,001)$, у третім та четвертій групах тварин - y 1,5 раза ( $<<0,001)$, а в п’ятій і шостій дослідних групах було повернення показників процесів ліпопероксидації до показників контрольної групи (табл. 2).

Таблищя 2. Показники концентрації продуктів ПОЛ, ферментів АОС у сироватці крові щурів на 30 добу $(\mathrm{M} \pm \mathrm{m})$

\begin{tabular}{|c|c|c|c|c|}
\hline $\begin{array}{c}\text { Група тварин, } \\
\text { дослідні препарати }\end{array}$ & $\begin{array}{c}\text { МДА } \\
\text { (кмоль/л) }\end{array}$ & $\begin{array}{c}\text { сод } \\
\text { (мккат/л) }\end{array}$ & $\begin{array}{l}\text { Каталаза } \\
\text { (мккат/л) }\end{array}$ & АПІ \\
\hline І. Контроль $(\mathrm{n}=10)$ & $2,35 \pm 0,03$ & $7,46 \pm 0,27$ & $0,263 \pm 0,012$ & 3,29 \\
\hline $\begin{array}{l}\text { II. Група порівняння } \\
(\mathrm{n}=10)\end{array}$ & $4,42 \pm 0,05_{\text {○○。 }}^{* * *}$ & $5,11 \pm 0,18$ 赵。 & $0,181 \pm 0,008$ 。 ○ 。 & 1,197 \\
\hline III. Nano Gen $(n=10)$ & $3,51 \pm 0,05 \begin{array}{c}* * * \\
\circ \text { ○。 }\end{array}$ & $5,63 \pm 0,15$ 。 。 。 & $0,205 \pm 0,009 \underset{\circ}{* * *}$ & 1,66 \\
\hline IV. MTA $(n=10)$ & $\begin{array}{c}3,45 \pm 0,05 \stackrel{* * *}{* *} \\
\circ\end{array}$ & $5,75 \pm 0,12 \underset{\substack{* \\
\circ}}{* * *}$ & $0,211 \pm 0,011$ 幽 & 1,73 \\
\hline $\begin{array}{l}\text { V. Композиція на основі } \\
\beta \text {-ТКФ }(n=10)\end{array}$ & $2,43 \pm 0,03$ 。。 & $6,87 \pm 0,15^{\circ \circ \circ}$ & $0,236 \pm 0,009 \circ \circ \circ$ & 2,94 \\
\hline $\begin{array}{l}\text { VI. Композиція на основі } \\
\text { ГА }(n=10)\end{array}$ & $2,41 \pm 0,02 \circ \circ \circ$ & $7,12 \pm 0,17^{\circ \circ \circ}$ & $0,241 \pm 0,008^{\circ \circ \circ}$ & 3,29 \\
\hline
\end{tabular}

Примітки: 1) * - показник вірогідності різниці порівняно з контролем при $р<0,05 ; 2) * *-p<0,01 ; 3)$ *** - p<0,001; 4) ${ }^{\circ}$ - показник вірогідності різниці порівняно з групою порівняння при $\left.\left.p<0,05 ; 5\right){ }^{\circ \circ}-p<0,01 ; 6\right)^{\circ \circ 0}-p<0,001$.

Одночасно $з$ цим були зміни в активності ферментів антиоксидантної системи. Так, у другій групі тварин концентрація СОд та каталази зменшились у 1,5 раза відповідно ( $<<0,001)$, а в тварин третьої і четвертої груп активність ферментів знизилась у 1,3 раза $(\mathrm{p}<0,001)$. Проте варто зазначити, що концентрація СОД та каталази у тварин п’ятої і шостої дослідних груп наблизилась до показників норми.
На 30 добу експерименту індекс АПІ в другій групі дослідних тварин зменшився на 64 $\%$, а в третій і четвертій групах - на 49 та $47 \%$ відповідно ( $<0,001)$. У п’ятій групі індекс АПІ знизився лишена 11 \% відповідно, порівняно 3 інтактними тваринами $(\mathrm{p}<0,001)$, а в шостій дослідній групі індекс АПІ наблизився до показників інтактних тварин. 
Висновки. Композиції на основі гідроксіапатиту і $\beta$-трикальційфосфату володіють антиоксидантними властивостями, пригнічують процеси надмірної ліпопероксидації, сприяють зменшенню активності запального процесу i,

\section{Список літератури}

1. Biomaterials for promoting periodontal regeneration in human intrabony defects: a systematic review / Anton Sculean, Dimitris Nikolidakis, George Nikou, Aleksandar Ivanovic // Periodontology. - 2015. - Vol. 68. - P. 182-216.

2. Calcium hydroxide in endodontics / Aayushi, Arundeep, Dax, Ravjot // Journal of Applied Dental and Medical Sciences. - 2016. - Vol. 2 (3). - P. 78-88.

3. Bansal R. Current overview on challenges in regenerative endodontics / R. Bansal, A. Jain, S. Mittal // J. Conserv. Dent. - 2015. - Vol. 18 (1). - P. 1-6.

4. Зубачик В. М. Порівняльна оцінка остеотропної дії ендодонтичних пломбувальних матеріалів на моделі експериментальної деструкції кісткової тканини щелепи щурів / В. М. Зубачик, І. В. Ган // Український стоматологічний альманах. - 2016. - № 1, T. 2. - C. 12-16.

5. Деньга О. В. Біохімічні показники колозубних тканин при експериментальній терапії періодонтиту / О. В. Деньга, Д. Б. Цевух, А. П. Левицький // Вісник стоматології. - 2007. - № 4. - С. 40-45.

\section{References}

1. Sculean, A. Nikolidakis, D. Nikou, G., \& Aleksandar Ivanovic, A. (2015). Biomaterials for promoting periodontal regeneration in human intrabony defects: a systematic review. Periodontology, 2000 (68), 182-216. 2. Aayushi, Arundeep, Dax, \& Ravjot (2016). Calcium hydroxide in endodontics. Journal of Applied Dental and Medical Sciences, 2 (3), 78-88.

3. Bansal, R. Jain, A., \& Mittal, S. (2015). Current overview on challenges in regenerative endodontics. J. Conserv. Dent., 18 (1), 1-6.

4. Zubachyk, V.M., \& Han, I.V. (2016). Porivnialna otsinka osteotropnoi dii endodontychnykh plombuvalnykh materialiv na modeli eksperymentalnoi destruktsii kistkovoi tkanyny shchelepy shchuriv [Comparative evaluation of osteotropic action of endodontic filling materials on the model of experimental destruction of bone tissue of the jaw of rats]. Ukrainskyi stomatolohichnyi almanakh-Ukrainian Dental Almanac, 1 (2), 12-16 [in Ukrainian].

5. Denha, O.V., Tsevukh, D.B., \& Levytskyi, A.P. (2007). Biokhimichni pokaznyky kolozubnykh tkanyn pry eksperymentalnii terapii periodontytu [Biochemical indices of collarbone tissues during experimental periodontitis treatment]. Visnyk stomatolohii - Herald of Dentistry, 4, 40-45 [in Ukrainian].

6. Ivchenko, A.V. (2012). Khimichnyi sklad reheneratu kistkovoi tkanyny, shcho formuietsia v mistsi defektu, na foni streptozototsynovoho diabetu $u$ shchuriv тим самим, стимулюють регенерацію кісткової тканини. Це дає змогу рекомендувати використання запропонованих композицій при лікуванні хворих на періодонтит хронічного перебігу з набутою широкою верхівкою кореня зуба.

6. Івченко А. В. Хімічний склад регенерату кісткової тканини, що формується в місці дефекту, на фоні стрептозотоцинового діабету у щурів статевозрілого віку / А. В. Івченко // Запорожский медицинский журнал. - 2012. - № 1 (70). - С. 14-16.

7. Лисенко О. С. Остеостимулююча активність остеотропних композицій на основі наноструктурованої біокераміки / О. С. Лисенко, А. П. Левицький, А. В. Борисенко // Вісник стоматології. - 2014. - № 1. - С. 2-7. 8. Любченко О. В. Порівняльна оцінка протизапальних та антиоксидантних властивостей пломбувальних цементів «Ретапекс» і «PRO ROOT MTA» на моделі експериментального періодонтиту / О. В. Любченко // Вісник стоматології. - 2011. № 2. - C. 5-9.

9. Юровська І. О. Клініко-морфологічні особливості перебігу та лікування хронічного періодонтиту в зубах з різним станом апікальної конструкції : дис. ... канд. мед. наук : 14.01.22 «Стоматологія» / I. О. Юровська; Нац. мед. акад. ім. П. Л. Шупика. К. , 2011. - 163 c.

statevozriloho viku [The chemical composition of the bone tissue regeneration that is formed at the defect site, in the context of streptotrozine diabetes in rats of mature age]. Zaporozhskiy meditsinskiy zhurnal Zaporozhye Medical Journal, 1 (70), 14-16 [in Ukrainian]. 7. Lysenko, O.S. Levytskyi, A.P., \& Borysenko, A.V. (2014). Osteostymuliuiucha aktyvnist osteotropnykh kompozytsii na osnovi nanostrukturovanoi biokeramiky [Osteostimulating activity of osteotropic compositions on the basis of nanostructured bioceramics]. Visnyk stomatolohii - Herald of Dentistry, 1, 2-7 [in Ukrainian]. 8. Liubchenko, O.V. (2011). Porivnialna otsinka protyzapalnykh ta antyoksydantnykh vlastyvostei plombuvalnykh tsementiv „Retapeks” i „PRO ROOT MTA” na modeli eksperymentalnoho periodontytu [Comparative estimation of anti-inflammatory and antioxidant properties of filling cements "Retapex" and «PRO ROOT MTA» on the model of experimental periodontitis]. Visnyk stomatolohii - Herald of Dentistry, 2, 5-9 [in Ukrainian]. 9. Yurovska, I.O. (2011). Kliniko-morfolohichni osoblyvosti perebihu ta likuvannia khronichnoho periodontytu $\mathrm{v}$ zubakh $\mathrm{z}$ riznym stanom apikalnoi konstryktsii [Clinical and morphological features of the course and treatment of chronic periodontitis in teeth with different state of apical constriction]. Candidate's thesis. Kyiv [in Ukrainian].

Отримано 06.04.18 